\title{
Research Article \\ Recovery of Pure Silicon and Other Materials from Disposed Solar Cells
}

\author{
Lineesh Punathil (D), ${ }^{1}$ K. Mohanasundaram, ${ }^{2}$ K. S. Tamilselavan, ${ }^{3}$ \\ Ravishankar Sathyamurthy $\mathbb{D I}^{4}{ }^{4}$ and Ali J. Chamkha ${ }^{5,6}$ \\ ${ }^{1}$ Department of Chemical Engineering, KPR Institute of Engineering and Technology, Coimbatore 641407, India \\ ${ }^{2}$ Department of Electrical and Electronics Engineering, KPR Institute of Engineering and Technology, Coimbatore 641407, India \\ ${ }^{3}$ Department of Electronics and Communication Engineering, KPR Institute of Engineering and Technology, \\ Coimbatore 641407, India \\ ${ }^{4}$ Department of Mechanical Engineering, KPR Institute of Engineering and Technology, Coimbatore 641407, India \\ ${ }^{5}$ Faculty of Engineering, Kuwait College of Science and Technology, Doha, Kuwait \\ ${ }^{6}$ Institute of Research and Development, Duy Tan University, Da Nang 550000, Vietnam
}

Correspondence should be addressed to Lineesh Punathil; lineesh.p@kpriet.ac.in and Ali J. Chamkha; alichamkha@duytan.edu.vn

Received 19 January 2021; Revised 8 March 2021; Accepted 4 April 2021; Published 16 April 2021

Academic Editor: Joaquim Carneiro

Copyright (c) 2021 Lineesh Punathil et al. This is an open access article distributed under the Creative Commons Attribution License, which permits unrestricted use, distribution, and reproduction in any medium, provided the original work is properly cited.

\begin{abstract}
The disposal of used photovoltaic panels is increasing day by day around the world. Therefore, an efficient method for recycling disposed photovoltaic panel is required to decrease environmental pollution. This work is aimed at efficiently recovering pure silicon and other materials such as aluminium, silver, and lead from disposed solar cells using chemical treatments. Earlier, the pure silicon was recovered by treating the solar cells with hydrofluoric acid or mixture of hydrofluoric acid and other chemicals. The usage of hydrofluoric acid is eliminated in the present work as it is highly toxic and corrosive chemical. The pure silicon (99.9984\%) has been recovered by sequentially treating with three different chemicals. Aluminium, silver, and lead are also recovered as aluminium hydroxide, silver chloride, and lead oxide, respectively.
\end{abstract}

\section{Introduction}

The use of solar cells has been tremendously growing around the world as it is a nonpolluting device for power generation. In contrary, the quantity of end-of-life of solar cells and damaged solar cells is drastically increased [1]. The average life expectancy of solar panel is about 25-30 years. In worldwide, around 60 million tons of solar panels have become wastes as those are in the stage of end-of-life [2]. Therefore, an efficient method for recycling of disposed solar cells is a necessity as it causes serious environmental pollution.

A few works have carried out for recycling of photovoltaic panels by using various methods [3-9]. Doi et al. [3] have recovered solar cells from EVA laminated solar cells by dissolution method. Later, it is found that thermal treatment is more economical to remove EVA from solar cells [4, 5]. Further, dissolution of EVA of solar cells in various solvents with ultrasonic irradiation has been analyzed by Kim and Lee. [6] Dias et al. [7] have used chemical and thermal treatments to separate silver from the disposed solar cells.

To extract pure silicon from the solar cell, various chemical treatments have been used $[4,5,8]$. Hydrofluoric acid was the most common chemical used for separating silicon from the solar cell $[4,5]$. However, the usage of hydrofluoric acid has to be eliminated as it is a highly toxic and corrosive chemical. Therefore, the main objective of this work is to replace hydrofluoric acid with other chemicals and efficiently recover pure silicon from the disposed solar cells. In addition, the other materials present in the solar cells such as aluminium, silver, and lead have to be recovered. 


\section{Recovery of Pure Silicon}

2.1. Experimental Procedure. The outer part of the PV panel contains various materials such as glass, ethylene vinyl acetate glass, copper, steel, aluminium, and plastics. The outer part can be removed by thermal degradation, and the inner solar cell can be separated. Here, the recovery of pure silicon from inner solar cell is conducted. The solar cell mainly contains silicon (about $91.586 \%$ by weight) (Table 1 ). It also contains other materials such as aluminium at bottom layer, silver electrodes at top layer, and lead and antireflecting coating $\left(\mathrm{Si}_{3} \mathrm{~N}_{4}\right)$ at top layer. The p-type and n-type silicon wafers are situated in between antireflecting coating and aluminium layer.

The considered solar cell wafer sample for the experiment is shown in Figure 1. The blue color layer is the antireflecting coating $(\mathrm{SiNx})$, and the white lines are the silver electrode. Figure 2 shows the bottom aluminium layer of solar cell. To remove these materials (aluminium, silver, lead, and antireflecting coating), chemical treatment method is used. Earlier, hydrofluoric acid or mixture of hydrofluoric acid and other chemicals was used to remove the antireflecting coating, silver, lead, and p-n junction of the solar cell. The use of hydrofluoric acid is eliminated in the present work as it is highly toxic and corrosive chemical. Each layer is removed one by one using chemical treatments.

A few researchers have used $\mathrm{KOH}$ as a reagent to remove aluminium layer $[4,5]$. In this work, $\mathrm{NaOH}$ has been used to remove aluminium layer as it is more economical than $\mathrm{KOH}$. Similarly, silver electrodes are removed by treating with $\mathrm{HNO}_{3}[4,5]$. Klugmann-Radziemska et al. [4, 5] have used mixture of hydrofluoric acid and other acids to remove antireflecting coating. In the present work, the hydrofluoric acid is replaced with phosphoric acid as it is highly toxic. In addition, the use of other acids is eliminated. Therefore, the separation of unreacted acid and product will be easier by using the present method. The chemical reactions involve in the present work are described next.

2.2. Chemical Treatments. The aluminium layer is removed by treating the solar cell with $10 \mathrm{M} \mathrm{NaOH}$ solution for 5 minutes at $63^{\circ} \mathrm{C}$ temperature, and the chemical reaction is given below.

$$
2 \mathrm{Al}+2 \mathrm{NaOH}+6 \mathrm{H}_{2} \mathrm{O} \rightarrow 2 \mathrm{Na}^{+}+2 \mathrm{Al}(\mathrm{OH})_{4}^{-}+3 \mathrm{H}_{2} .
$$

The silver electrodes and lead from the solar cell are removed by treating with $6 \mathrm{M} \mathrm{HNO}_{3}$ for 5 minutes at $70^{\circ} \mathrm{C}$, and the chemical reactions are given below.

$$
\begin{aligned}
& \mathrm{Ag}+2 \mathrm{HNO}_{3} \rightarrow \mathrm{AgNO}_{3}+\mathrm{H}_{2} \mathrm{O}+\mathrm{NO}_{2} \\
& \mathrm{~Pb}+2 \mathrm{HNO}_{3} \rightarrow \mathrm{PbO}+\mathrm{H}_{2} \mathrm{O}+2 \mathrm{NO}_{2} .
\end{aligned}
$$

The antireflecting coating $\left(\mathrm{Si}_{3} \mathrm{~N}_{4}\right)$ is removed by treating with $90 \%$ phosphoric acid for 45 minutes at $70^{\circ} \mathrm{C}$. The volume of reagents, temperature, and time duration for treating the wafer at each stage are presented in Table 2.
TABLE 1: ICP-MS analysis of weight percentage of each element present in wafer.

\begin{tabular}{lcccc}
\hline Sample & $\mathrm{Si}$ & $\mathrm{Al}$ & $\mathrm{Ag}$ & $\mathrm{Pb}$ \\
\hline Before treating & 91.586 & 6.81 & 1.5551 & 0.044 \\
After treating & 99.9984 & 0.089 & 0.0117 & 0.0009 \\
\hline
\end{tabular}

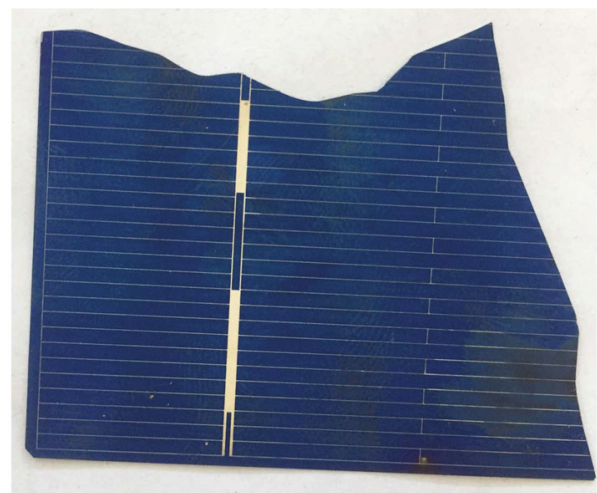

FIgURE 1: Top layer of solar cell which contains antireflecting coating and silver electrodes.

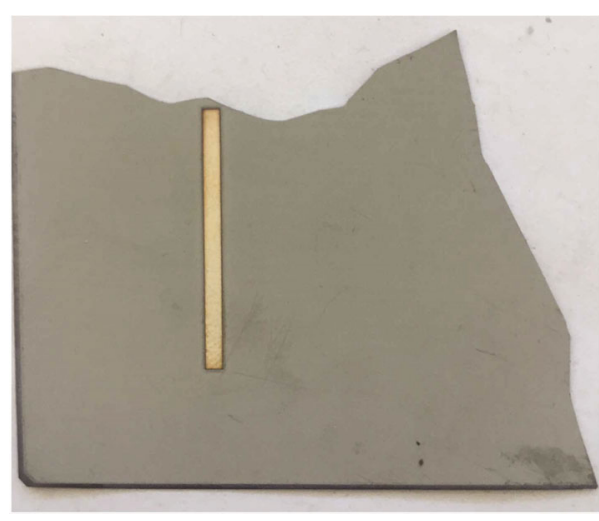

FIgURe 2: Bottom aluminium layer of solar cell.

\section{Experimental Results}

The aluminium layer is removed after treating with concentrated $\mathrm{NaOH}$ solution (Figure 3). The hydrogen formed during the reaction (Eq. (1)) is collected in a chamber and can be used as fuel. The aluminium hydroxide $\left(\mathrm{Al}(\mathrm{OH})_{3}\right)$ from $\mathrm{NaOH}$ solution is separated by filtration. Similarly, the silver and lead are removed by treating with $\mathrm{HNO}_{3}$ (Figure 4). The released $\mathrm{NO}_{2}$ is collected and can be used for the production of nitric acid. To separate silver nitrate $\left(\mathrm{AgNO}_{3}\right)$ (Eq. (2)), the solution is treated with $\mathrm{HCl}$, and silver chloride $(\mathrm{AgCl})$ is formed. The precipitated silver chloride is filtered out. Further, the solution is treated with $\mathrm{NaOH}$ to separate lead compound $(\mathrm{PbO})$ from the solution. The lead oxide is converted to lead hydroxide, and the precipitated lead hydroxide is filtered. 
TABLE 2: Volume of reagents, temperature, and duration for treatments at each stage.

\begin{tabular}{lccc}
\hline Reagents & $\mathrm{NaOH}$ & $\mathrm{HNO}_{3}$ & $\mathrm{H}_{3} \mathrm{PO}_{4}$ \\
\hline Volume $(\mathrm{ml})$ & 20 & 20 & 20 \\
Temperature $\left({ }^{\circ} \mathrm{C}\right)$ & 63 & 70 & 150 \\
Time (minutes) & 5 & 5 & 45 \\
\hline
\end{tabular}

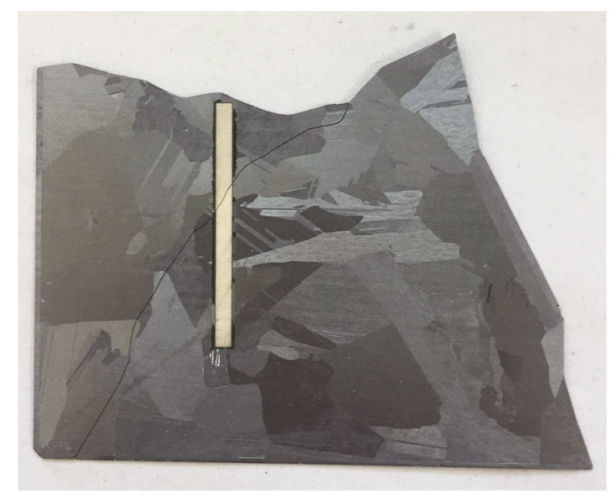

Figure 3: Bottom part of solar cell after removing aluminium layer.

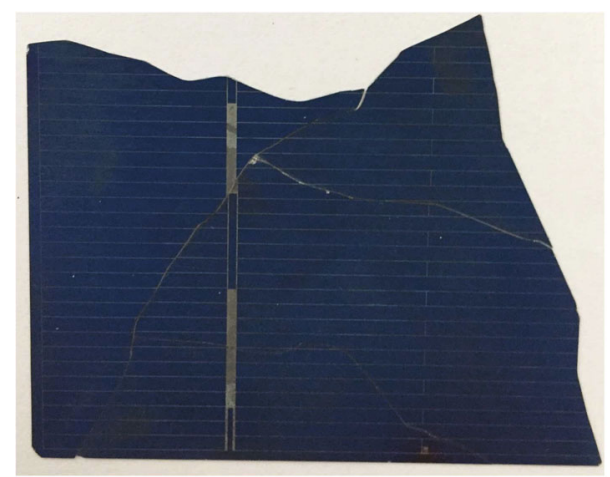

FIGURE 4: Top part of solar cell after removing silver electrodes and lead.

The antireflecting coating (blue in color) and p-n junction are the only impurities at present stage, and these impurities are removed by treating with concentrated phosphoric acid (Figure 5). The pure silicon silicon (99.9984\%) is obtained after this treatment. The weight percentage of each element present in the wafer before and after chemical treatments is analyzed using ICP-MS, and the data are tabulated in Table 1.

\section{Profit Analysis}

The profit analysis has been carried out based on recycling of $1 \mathrm{~kg}$ of solar cell. The masses of products obtained after recycling $1 \mathrm{~kg}$ solar cell are tabulated in Table 3 . The lead compound is neglected in calculation as it is very low in quantity. Similarly, cost of each product in market is also tabulated, and the profit obtained by each product is calculated.

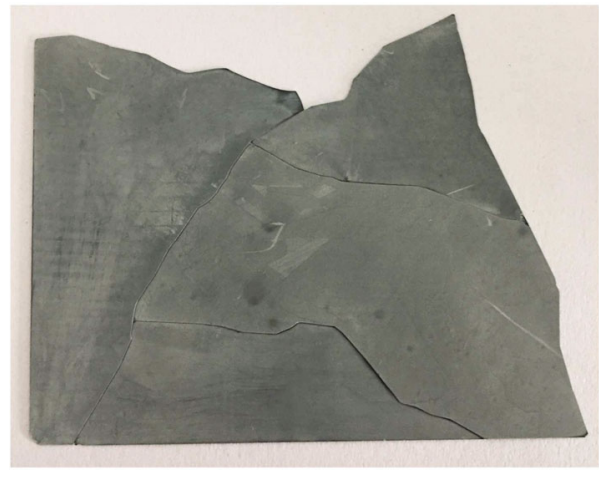

FIGURE 5: Top part of solar cell after removing antireflecting coating (pure silicon).

TABLE 3: Amount of products recovered, cost of products, and profit of products.

\begin{tabular}{lccc}
\hline Product obtained after recycling & $\mathrm{Si}$ & $\mathrm{Al}(\mathrm{OH})_{3}$ & $\mathrm{AgCl}$ \\
\hline Mass of products after recycling $(\mathrm{kg})$ & 0.9158 & 0.19464 & 0.02064 \\
Cost of product $(\$) / \mathrm{kg}$ & 7 & 1.21 & 120000 \\
Profit $(\$) / \mathrm{kg}$ of solar cell & 6.41 & 0.238 & 247.68 \\
\hline
\end{tabular}

The total profit by recycling $1 \mathrm{~kg}$ of solar cell is calculated by the following formula.

$$
P_{T}=P_{S}+P_{\mathrm{Al}}+P_{\mathrm{Ag}}-R_{C}
$$

Here, $P_{T}$ is the total profit, $P_{S}$ is the profit obtained by silicon, $P_{\mathrm{Al}}$ is the profit obtained by $\mathrm{Al}(\mathrm{OH})_{3}, P_{\mathrm{Ag}}$ is the profit obtained by $\mathrm{AgCl}$, and $R_{C}$ is the recycling cost.

Recycling cost for $1 \mathrm{~kg}$ solar cell is $68.9 \$$. Therefore, the total profit after recycling of $1 \mathrm{~kg}$ solar cell will be

$$
P_{T}(\$)=6.41+0.238+247.68-68.9=185.428 \$ \text {. }
$$

\section{Conclusions}

A method for recovering pure silicon from the disposed solar cell using chemical treatments has been presented in this work. The use of highly toxic chemical such as hydrofluoric acid is eliminated, and other chemicals have been effectively used for treatments. The pure silicon (99.9984\%) has been recovered using this method, and the response of recovered silicon towards DC voltage has been analyzed. The silicon is not conducting electric current as it is pure silicon. The recovered silicon can be used for manufacturing new solar cell or electronic components such as diode, transistor, and microchip.

The other materials present in solar cell such as aluminium, silver, and lead are recovered as aluminium hydroxide, silver chloride, and lead hydroxide, respectively. The sequential chemical treatments of solar cell are used in this method. Therefore, the compounds from the treated solution are easily separated. The profit analysis for recycling $1 \mathrm{~kg}$ of solar cell has been conducted, and it is observed that the solar cell recycling is highly profitable. 


\section{Data Availability}

The data obtained in this work by ICP-MS analysis is performed at South India Textile Research AssociationCoimbatore.

\section{Conflicts of Interest}

The authors declare that they have no conflicts of interest.

\section{References}

[1] F. C. Padoan, P. Altimari, and F. Pagnanelli, "Recycling of end of life photovoltaic panels: a chemical prospective on process development," Solar Energy, vol. 177, pp. 746-761, 2019.

[2] S. Weckend, A. Wase, and G. Heath, End-of-life managementsolar photovoltaic panels, International Renewable Energy Agency (IRENA), Abu Dhabi, 2016.

[3] T. Doi, I. Tsuda, H. Unagida, A. Murata, K. Sakuta, and K. Kurokawa, "Experimental study on PV module recycling with organic solvent method," Solar Energy Materials and Solar Cells, vol. 67, no. 1-4, pp. 397-403, 2001.

[4] E. Klugmann-Radziemska and P. Ostrowski, "Chemical treatment of crystalline silicon solar cells as a method of recovering pure silicon from photovoltaic modules," Renewable Energy, vol. 35, no. 8, pp. 1751-1759, 2010.

[5] E. Klugmann-Radziemska, P. Ostrowski, K. Drabczyk, P. Panek, and M. Szkodo, "Experimental validation of crystalline silicon solar cells recycling by thermal and chemical methods," Solar Energy Materials and Solar Cells, vol. 94, no. 12, pp. 22752282, 2010.

[6] Y. Kim and J. Lee, "Dissolution of ethylene vinyl acetate in crystalline silicon PV modules using ultrasonic irradiation and organic solvent," Solar Energy Materials and Solar Cells, vol. 98, pp. 317-322, 2012.

[7] P. Dias, S. Javimczik, M. Benevit, and H. Veit, "Recycling WEEE: extraction and concentration of silver from waste crystalline silicon photovoltaic modules," Recycling WEEE: Extraction and concentration of silver from waste crystalline silicon photovoltaic modules, Waste Management, vol. 57, pp. 220225, 2016.

[8] W.-H. Huang, W. J. Shin, L. Wang, and W.-C. Sun, "Strategy and technology to recycle wafer-silicon solar modules," Solar Energy, vol. 144, pp. 22-31, 2017.

[9] V. Fiandra, L. Sannino, C. Andreozzi, and G. Graditi, "End-oflife of silicon PV panels: a sustainable materials recovery process," Waste Management, vol. 84, pp. 91-101, 2019. 